\title{
Impact of Mobile Health Devices for the Detection of Atrial Fibrillation: Systematic Review
}

Tom E Biersteker, MD; Martin J Schalij, MD, PhD; Roderick W Treskes, MD, PhD

Leiden University Medical Center, Leiden, Netherlands

Corresponding Author:

Martin J Schalij, MD, PhD

Leiden University Medical Center

Albinusdreef 2

Leiden

Netherlands

Phone: 31715262020

Email: m.j.schalij@lumc.nl

\section{Abstract}

Background: Atrial fibrillation (AF) is the most common arrhythmia, and its prevalence is increasing. Early diagnosis is important to reduce the risk of stroke. Mobile health (mHealth) devices, such as single-lead electrocardiogram (ECG) devices, have been introduced to the worldwide consumer market over the past decade. Recent studies have assessed the usability of these devices for detection of AF, but it remains unclear if the use of mHealth devices leads to a higher AF detection rate.

Objective: The goal of the research was to conduct a systematic review of the diagnostic detection rate of AF by mHealth devices compared with traditional outpatient follow-up. Study participants were aged 16 years or older and had an increased risk for an arrhythmia and an indication for ECG follow-up-for instance, after catheter ablation or presentation to the emergency department with palpitations or (near) syncope. The intervention was the use of an mHealth device, defined as a novel device for the diagnosis of rhythm disturbances, either a handheld electronic device or a patch-like device worn on the patient's chest. Control was standard (traditional) outpatient care, defined as follow-up via general practitioner or regular outpatient clinic visits with a standard 12-lead ECG or Holter monitoring. The main outcome measures were the odds ratio (OR) of AF detection rates.

Methods: Two reviewers screened the search results, extracted data, and performed a risk of bias assessment. A heterogeneity analysis was performed, forest plot made to summarize the results of the individual studies, and albatross plot made to allow the $P$ values to be interpreted in the context of the study sample size.

Results: A total of 3384 articles were identified after a database search, and 14 studies with a 4617 study participants were selected. All studies but one showed a higher AF detection rate in the mHealth group compared with the control group (OR 1.00-35.71), with all RCTs showing statistically significant increases of AF detection (OR 1.54-19.16). Statistical heterogeneity between studies was considerable, with a Q of 34.1 and an $I^{2}$ of 61.9, and therefore it was decided to not pool the results into a meta-analysis.

Conclusions: Although the results of 13 of 14 studies support the effectiveness of mHealth interventions compared with standard care, study results could not be pooled due to considerable clinical and statistical heterogeneity. However, smartphone-connectable ECG devices provide patients with the ability to document a rhythm disturbance more easily than with standard care, which may increase empowerment and engagement with regard to their illness. Clinicians must beware of overdiagnosis of AF, as it is not yet clear when an mHealth-detected episode of AF must be deemed significant.

(JMIR Mhealth Uhealth 2021;9(4):e26161) doi: $\underline{10.2196 / 26161}$

\section{KEYWORDS}

eHealth; mHealth; telemedicine; cardiology; atrial fibrillation; systematic review

\section{Introduction}

Atrial fibrillation (AF) is the most commonly diagnosed arrhythmia [1]. It may be paroxysmal (present for 30 seconds to 7 days), persistent (present for more than 7 days), or permanent [2]. Risk factors for AF are diverse and include advanced age, male gender, diabetes mellitus, hypertension, obesity, valvular disease, obstructive sleep apnea, heart failure, 
and previous myocardial infarction [3]. Among other symptoms, AF can cause palpitations, dyspnea, and tiredness. Patients can, however, be asymptomatic [4].

The worldwide prevalence of AF is increasing. This increase has been attributed to an aging population and increased prevalence of cardiovascular risk factors [5]. A European study has shown that the number of patients with diagnosed AF is expected to increase from a prevalence of $2.3 \%$ in 2010 to $3.5 \%$ to $4.3 \%$ in 2050 [6]. Due to an increased risk of stroke, AF is associated with increased risk of mortality [7]. Compared with patients with sinus rhythm, those with AF are found to have a 2.4-fold risk of stroke, and the risk of ischemic heart disease and development of chronic kidney disease are both increased 1.6-fold [8].

Early diagnosis of AF and prophylactic treatment for ischemic stroke with oral anticoagulants is therefore important, whether the AF is paroxysmal, persistent, or permanent and symptomatic or silent [2]. Moreover, it has been demonstrated that excessive supraventricular ectopic activity, defined as the presence of either $\geq 30$ premature atrial contractions (PACs) per hour daily or any runs of $\geq 20$ PACs, increases the risk of stroke in patients with a $\mathrm{CHA}_{2} \mathrm{DS}_{2}$-VASc (congestive heart failure, hypertension, age $\geq 75$ years, diabetes mellitus, stroke or transient ischemic attack [TIA], vascular disease, age 65 to 74 years, sex category) score of $\geq 2$ by $2.4 \%$ [9].

Traditionally, patients are diagnosed with AF using a 12-lead electrocardiogram (ECG). In case of suspected paroxysmal AF, it is possible to perform prolonged monitoring via Holter registration. However, as paroxysmal AF is often silent and patients can have vast periods of sinus rhythm, diagnosing paroxysmal AF is a challenge [10].

Over the last decade, consumer grade health monitoring devices have been developed and marketed as beneficial for personal health monitoring [11]. Among those devices are several different smartphone connectable ECG devices. The majority are lead-I ECG devices, handheld instruments that register lead I of the ECG, measuring the electric current generated by the myocardium by using the fingers of the right and the left hand [12]. These devices are typically used for spot-checks. Another group of devices is meant for continuous monitoring and involve patches that stick to the chest and allow monitoring of the heart rate and rhythm continuously for up to 2 weeks [13]. Both groups of devices can be seen as mobile health (mHealth) devices and used for AF screening [12].

Studies have been done to assess the accuracy of mHealth devices compared with 12-lead ECGs. A recent systematic review suggests several $\mathrm{mHealth}$ devices are suitable in the use of detecting AF, based on the sensitivity and specificity of these devices [14]. However, it is still unclear if and to what extent the use of mHealth devices leads to higher detection rates of AF. Therefore, the objective of this systematic review is to evaluate studies comparing the detection rate of AF by mHealth devices with more traditional outpatient follow-up.

\section{Methods}

\section{Literature Review and Definitions}

A systematic literature review was conducted to evaluate the efficacy of mHealth devices using standard (traditional) care as the reference standard in people with an indication for follow-up for a suspected arrythmia (eg, after catheter ablation or electrical cardioversion) or in cases of an acute emergency department presentation with (near) syncope or palpitations where no arrhythmia could be found at the time of presentation. The efficacy of mHealth was defined as the detection rate of AF by a smartphone-connectable ECG device, either a handheld electronic device or patch-like device attached to the study subject's chest or by requiring subject to send an ECG transtelephonically. Standard care was defined as follow-up via a general practitioner or regular outpatient clinic visit with a standard 12-lead ECG or Holter monitoring. This systematic review was conducted and reported by following the Cochrane Handbook for Systematic Reviews of Interventions [15].

\section{Eligibility Criteria}

The eligibility criteria for studies to be included in this systematic review were as follows:

- $\quad$ Published studies comparing mHealth devices with standard care in patients with an indication for follow-up via ECG or Holter monitoring

- Studies with AF detection as a primary or secondary outcome measure

- Studies conducted in people aged 16 years and older reporting demographic data such as patient characteristics, study setting, sample size, and data points

- Studies performed in a clinical or outpatient setting

- Studies in patients without an internal cardioverter defibrillator, pacemaker, or ventricular assist device

Studies had to be published in English or Dutch to be selected. If a study has been indexed in multiple databases, only the PubMed version was included.

\section{Literature Search Strategy}

The search strategy is presented in Multimedia Appendix 1. No study design filters were applied, and all electronic databases were searched for articles from Jan 1, 2005, until February 19, 2020. The following databases were searched: Medline, Embase, PubMed, Web of Science, Emcare, Academic Search Premier, and the Cochrane Library. The search results were managed using EndNote X9 software (Clarivate Analytics). Relevant studies and reviews were manually searched to identify other possible relevant studies.

\section{Article Selection and Data Synthesis}

A 2-stage process was used for inclusion in the review. Two reviewers (TB, RT) first independently screened all titles and abstracts of the identified studies to find potentially relevant studies. The same reviewers then assessed the full-text articles independently for the eligibility criteria. Any disagreements were resolved by consensus. 


\section{Risk of Bias Assessment}

Risk of bias was assessed with the RoB 2 (Risk of Bias 2) tool for randomized controlled trials (RCTs) and the ROBINS-I (Risk of Bias in Nonrandomized Studies of Interventions) tool for nonrandomized studies $[16,17]$. This is in accordance with the Cochrane Handbook's recommendations [15]. The risk of bias had 3 levels: low risk of bias, some concerns, and high risk of bias.

\section{Summary Measures}

The primary outcome measure of this systematic review was the odds ratio (OR) of AF detection, comparing mHealth devices to standard care. The PATCH-ED (Patch Monitor in Patients With Unexplained Syncope After Initial Evaluation in the Emergency Department) and IPED (Investigation of Palpitations in the Emergency Department) study groups reported no events in the control groups $[18,19]$. Therefore, the Haldane correction was used [20]. A heterogeneity analysis between studies was performed with a chi-square test [15]. A forest plot was made to summarize the results of individual studies. Finally, an albatross plot was made to allow the $P$ values to be interpreted in the context of study sample size. The contour lines of albatross plots are formed by hypothetical effect sizes [21]. In this case, this concerns odds ratios due to the outcome being dichotomous. The forest and albatross plots were made in Matlab (The Mathworks Inc).

\section{Results}

\section{Study Selection}

As of October 19, 2020, a total of 3384 articles were obtained from the database searches. Two investigators (TB and RT) excluded 3350 studies based on the title and abstract. A total of 34 abstracts meeting the eligibility criteria were identified. After reviewing the full text, the reviewers chose 14 studies with a total of 4617 study subjects. The selection process is shown in Figure 1. The kappa statistic for interrater reliability was .81, showing substantial agreement between the 2 investigators [22]. 
Figure 1. Study search and selection process.

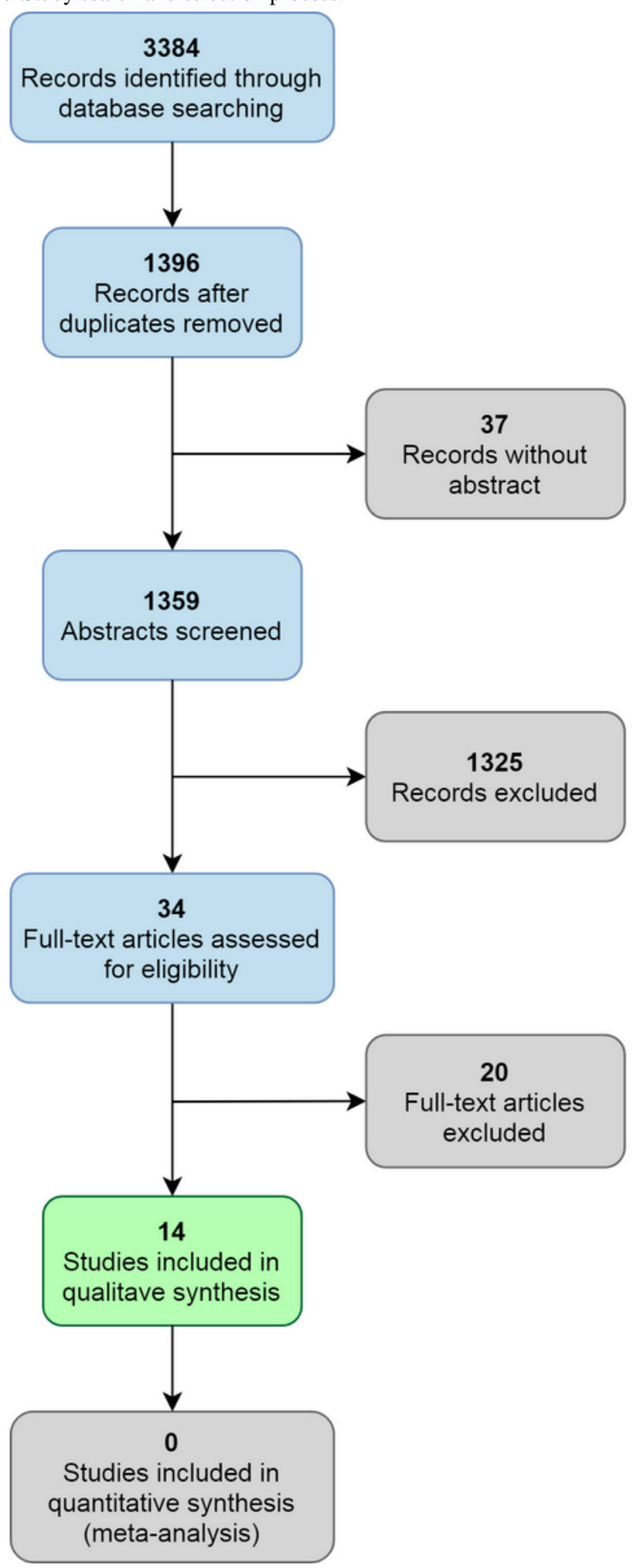

\section{9 non-English}

1233 irrelevant to this review 39 studies in patients with ICD/pacemaker 21 Rationale \& Design articles 3 studies in children
1 more study in patients with ICD/pacemaker 15 studies without control group 3 mHealth-comparison studies 1 study failed to report demographic data

\section{Study Characteristics}

The 14 selected studies consist of 8 cohort studies, 4 RCTs, and 2 case-control studies [18,19,23-34]. Table 1 shows participant and study characteristics. Study populations were heterogenous: some studies included only patients without any history of AF, others included only patients with earlier documented AF. Participant genders varied between the study populations: $42 \%$ to $87 \%$ were male. Mean age varied from 44 to 73 years. 
Table 1. Study characteristics.

\begin{tabular}{|c|c|c|c|c|c|c|c|}
\hline $\begin{array}{l}\text { Author, year, } \\
\text { country }\end{array}$ & Study type & Patient charactertistics & $\begin{array}{l}\text { Sample size; drop } \\
\text { out; mean age; } \\
\text { male }\end{array}$ & Intervention & Control & $\begin{array}{l}\text { Follow- } \\
\text { up }\end{array}$ & Primary outcome \\
\hline $\begin{array}{l}\text { Liu et al } \\
(2010), \text { China } \\
{[23]}\end{array}$ & $\begin{array}{l}\text { Prospective } \\
\text { cross-sectional }\end{array}$ & Catheter ablation patients & $\begin{array}{l}92 ; 0(0 \%) ; 54 \mathrm{y}^{\mathrm{a}} ; \\
78 \% \text { male }\end{array}$ & $\begin{array}{l}\text { Transtelephonic } \\
\mathrm{ECG}^{\mathrm{b}} \text { once dai- } \\
\text { ly }\end{array}$ & $\begin{array}{l}24 \mathrm{~h} \text { Holter+ } \\
\text { at complaints }\end{array}$ & $90 \mathrm{~d}^{\mathrm{c}}$ & $\mathrm{AF}^{\mathrm{d}}$ detection \\
\hline $\begin{array}{l}\text { Rosenberg et } \\
\text { al (2013), US } \\
{[24]}\end{array}$ & $\begin{array}{l}\text { Prospective } \\
\text { cross-sectional }\end{array}$ & $\begin{array}{l}\text { Patients who are managed } \\
\text { for AF, no definition was } \\
\text { given }\end{array}$ & $\begin{array}{l}74 ; 0(0 \%) ; 65 \mathrm{y} \\
55 \% \text { male }\end{array}$ & ZioPatch & $24 \mathrm{~h} \mathrm{Holter}$ & $14 \mathrm{~d}$ & $\mathrm{AF}$ detection \\
\hline $\begin{array}{l}\text { Barrett et al } \\
\text { (2013), US } \\
{[25]}\end{array}$ & $\begin{array}{l}\text { Prospective } \\
\text { cross-sectional }\end{array}$ & $\begin{array}{l}\text { Outpatients with indication } \\
\text { for Holter monitoring }\end{array}$ & $\begin{array}{l}146 ; 4(2.7 \%) \\
\text { n/a } ; n / a\end{array}$ & ZioPatch & $24 \mathrm{~h}$ Holter & $14 \mathrm{~d}$ & $\begin{array}{l}\text { Arrhythmia detec- } \\
\text { tion }\end{array}$ \\
\hline $\begin{array}{l}\text { Hendrikx et al } \\
(2014), \text { Swe- } \\
\text { den [26] }\end{array}$ & $\begin{array}{l}\text { Prospective } \\
\text { cross-sectional }\end{array}$ & $\begin{array}{l}\text { Patients with unexplained } \\
\text { palpitations or presyncope }\end{array}$ & $\begin{array}{l}95 ; 0(0 \%) ; 54 \mathrm{y} \\
44 \% \text { male }\end{array}$ & $\begin{array}{l}\text { Zenicor twice } \\
\text { daily }+24 \mathrm{~h}^{\mathrm{f}} \\
\text { Holter }\end{array}$ & $24 \mathrm{~h}$ Holter & $28 \mathrm{~d}$ & $\begin{array}{l}\text { Arrhythmia detec- } \\
\text { tion }\end{array}$ \\
\hline $\begin{array}{l}\text { Kimura et al } \\
(2016), \text { Japan } \\
{[27]}\end{array}$ & $\begin{array}{l}\text { Prospective } \\
\text { cross-sectional }\end{array}$ & Catheter ablation patients & $\begin{array}{l}28 ; 2(6.7 \%) ; 59 y \\
87 \% \text { male }\end{array}$ & $\begin{array}{l}\text { CardioPhone } \\
\text { twice daily }\end{array}$ & $\begin{array}{l}\text { Monthly } 24 \text { h } \\
\text { Holter }\end{array}$ & $6 \mathrm{mo}^{\mathrm{g}}$ & AF detection \\
\hline $\begin{array}{l}\text { Busch et al } \\
\text { (2017), Ger- } \\
\text { many [28] }\end{array}$ & $\begin{array}{l}\text { Retrospective } \\
\text { cross-sectional }\end{array}$ & $\begin{array}{l}\text { Volunteers to join in an } \\
\text { mHealth }^{\mathrm{h}} \text { study }\end{array}$ & $\begin{array}{l}1678 ; \mathrm{n} / \mathrm{a} ; 51 \mathrm{y} \\
48 \% \text { male }\end{array}$ & $\begin{array}{l}\text { SensorMobile } \\
\text { twice daily }\end{array}$ & $\begin{array}{l}\text { Single 12-lead } \\
\text { ECG }\end{array}$ & $28 \mathrm{~d}$ & AF detection \\
\hline $\begin{array}{l}\text { Halcox et al } \\
\text { (2017), UK } \\
{[29]}\end{array}$ & $\begin{array}{l}\text { Single center, } \\
\text { open label } \mathrm{RCT}^{\mathrm{i}}\end{array}$ & $\begin{array}{l}\geq 65 \text { y patients without } \mathrm{AF} \\
\text { at a } \mathrm{GP}^{\mathrm{j}} \text { practice }\end{array}$ & $\begin{array}{l}1001 ; 5(0.5 \%) ; 73 \\
\mathrm{y} ; 47 \% \text { male }\end{array}$ & $\begin{array}{l}\text { AliveCor Kar- } \\
\text { dia twice a } \\
\text { week }\end{array}$ & $\begin{array}{l}\text { Follow-up at } \\
\text { the GP }\end{array}$ & $1 \mathrm{y}$ & $\begin{array}{l}\text { Time to diagnosis } \\
\text { of } \mathrm{AF}\end{array}$ \\
\hline $\begin{array}{l}\text { Hickey et al } \\
\text { (2017), US } \\
{[30]}\end{array}$ & $\begin{array}{l}\text { Prospective, } \\
\text { matched cohort } \\
\text { study }\end{array}$ & Patients with a history of AF & $\begin{array}{l}46 ; 0(0 \%) ; 55 \mathrm{y} \\
65 \% \text { male }\end{array}$ & $\begin{array}{l}\text { AliveCor Kar- } \\
\text { dia once daily }\end{array}$ & $\begin{array}{l}\text { Standard care } \\
\text { (no added } \\
\text { care) }\end{array}$ & $6 \mathrm{mo}$ & $\begin{array}{l}\text { Atrial arrhythmia } \\
\text { detection }\end{array}$ \\
\hline $\begin{array}{l}\text { Narasimha et } \\
\text { al (2018), US } \\
{[31]}\end{array}$ & $\begin{array}{l}\text { Prospective } \\
\text { cross-sectional }\end{array}$ & $\begin{array}{l}\text { Patients with unexplained } \\
\text { palpitations who underwent } \\
\text { previous Holter monitoring }\end{array}$ & $\begin{array}{l}33 ; 5(13.2 \%) ; 48 \\
\mathrm{y} ; 42 \% \text { male }\end{array}$ & $\begin{array}{l}\text { AliveCor Kar- } \\
\text { dia at com- } \\
\text { plaints }\end{array}$ & $\begin{array}{l}\text { External loop } \\
\text { recorder }\end{array}$ & $30 \mathrm{~d}$ & $\begin{array}{l}\text { Arrhythmia detec- } \\
\text { tion }\end{array}$ \\
\hline $\begin{array}{l}\text { Reed et al } \\
(2018), \text { Scot- } \\
\text { land [18] }\end{array}$ & $\begin{array}{l}\text { Prospective, un- } \\
\text { matched case- } \\
\text { control study }\end{array}$ & $\begin{array}{l}\geq 16 \text { y ER patients with unex- } \\
\text { plained syncope }\end{array}$ & $\begin{array}{l}689 ; 0(0 \%) ; 67 \mathrm{y} \\
47 \% \text { male }\end{array}$ & ZioPatch & $\begin{array}{l}\text { Standard care } \\
\text { (no added } \\
\text { care) }\end{array}$ & $14 \mathrm{~d}$ & $\begin{array}{l}\text { Symptomatic } \\
\text { rhythm detection }\end{array}$ \\
\hline $\begin{array}{l}\text { Reed et al } \\
\text { (2019), Scot- } \\
\text { land [19] }\end{array}$ & $\begin{array}{l}\text { Multicenter, } \\
\text { open label RCT }\end{array}$ & $\begin{array}{l}\geq 16 \text { y ER patients with unex- } \\
\text { plained palpitations or } \\
\text { (pre)syncope }\end{array}$ & $\begin{array}{l}240 ; 2(0.8 \%) ; 40 \\
y ; 44 \% \text { male }\end{array}$ & $\begin{array}{l}\text { Alivecor Kardia } \\
\text { at complaints }\end{array}$ & $\begin{array}{l}\text { Standard care } \\
\text { (no added } \\
\text { care) }\end{array}$ & $90 \mathrm{~d}$ & $\begin{array}{l}\text { Symptomatic } \\
\text { rhythm detection }\end{array}$ \\
\hline $\begin{array}{l}\text { Goldenthal et } \\
\text { al (2019), US } \\
{[32]}\end{array}$ & $\begin{array}{l}\text { Single center, } \\
\text { open label RCT }\end{array}$ & $\begin{array}{l}\text { Patients with documented } \\
A F \text {, undergoing ablation or } \\
\mathrm{ECV}^{\mathrm{k}}\end{array}$ & $\begin{array}{l}238 ; 5(2.1 \%) ; 61 \\
\mathrm{y} ; 76 \% \text { male }\end{array}$ & $\begin{array}{l}\text { AliveCor Kar- } \\
\text { dia daily and at } \\
\text { complaints }\end{array}$ & $\begin{array}{l}\text { Standard care } \\
\text { (no added } \\
\text { care) }\end{array}$ & $6 \mathrm{mo}$ & AF detection \\
\hline $\begin{array}{l}\text { Karunadas et } \\
\text { al (2019), In- } \\
\text { dia [33] }\end{array}$ & $\begin{array}{l}\text { Prospective } \\
\text { cross-sectional }\end{array}$ & $\begin{array}{l}\text { Admitted patients to cardiol- } \\
\text { ogy ward who required } \\
\text { monitoring }\end{array}$ & $\begin{array}{l}141 ; 0(0 \%) ; 44 \mathrm{y} \\
53 \% \text { male }\end{array}$ & $\begin{array}{l}\text { WebCardio } \\
\text { (patch) }\end{array}$ & $24 \mathrm{~h} \mathrm{Holter}$ & $1 \mathrm{~d}$ & $\begin{array}{l}\text { Arrhythmia detec- } \\
\text { tion }\end{array}$ \\
\hline $\begin{array}{l}\text { Kaura et al } \\
\text { (2019), UK } \\
\text { [34] }\end{array}$ & $\begin{array}{l}\text { Multicenter, } \\
\text { open label RCT }\end{array}$ & $\begin{array}{l}\text { Non-AF patients with nonla- } \\
\text { cunar stroke or TIA }{ }^{1}\end{array}$ & $\begin{array}{l}116 ; 26(22.4 \%) \\
70 \mathrm{y} ; 47 \% \text { male }\end{array}$ & ZioPatch & $24 \mathrm{~h}$ Holter & $14 \mathrm{~d}$ & AF detection \\
\hline
\end{tabular}

$\mathrm{a}$ : year.

${ }^{\mathrm{b}}$ ECG: electrocardiogram.

${ }^{c}$ d: day.

${ }^{\mathrm{d}} \mathrm{AF}$ : atrial fibrillation.

${ }^{\mathrm{e}}$ Not applicable.

$\mathrm{f}_{\mathrm{h}}$ : hour.

$\mathrm{g}_{\text {mo: month. }}$

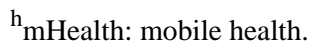

${ }^{\mathrm{i}} \mathrm{RCT}$ : randomized controlled trial.

${ }^{j}$ GP: general practice. 
${ }^{\mathrm{E}} \mathrm{ECV}$ : electrical cardioversion.

${ }^{1}$ TIA: transient ischemic attack.

A total of 9 studies used handheld devices such as the Kardia (AliveCor Inc) or Zenicor-ECG (Zenicor Medical Systems AB) as an intervention, while 5 studies used a patch such as the Zio (iRhythm Technologies Inc), which was placed on the participant's chest $[13,35,36]$. The duration of the intervention was 1 to 14 days for studies with patches and 28 days to 1 year for studies with handheld devices. All studies published data about AF detection, although AF detection was the primary outcome in only 6 studies. A total of 4 studies used detection of any arrhythmia (AF, atrial flutter, supraventricular or ventricular tachycardia, sinus pauses of more than 3 seconds, and second- and third-degree atrioventricular blocks), and 2 other studies reported symptomatic arrhythmias as the primary outcome; 1 study used atrial arrhythmia detection and the final study reported the time to AF diagnosis as the primary outcome. One study reported a composite endpoint of AF, ventricular tachycardia, and sinus pauses of more than 3 seconds instead [25].
A total of 6 studies used 24-hour Holter monitoring as standard care, with 1 study adding another 24-hour Holter monitoring when study patients experienced an episode of palpitations and another study adding another 24-hour Holter monitoring every month, 6 times in total. However, 5 studies only saw patients back in the outpatient clinic or general practitioner. One study used an external loop recorder as standard care, activated at complaints during the entire follow-up duration, and the final study documented one extra standard ECG as standard care. Holter timing was at the start of the study in 4 of 6 studies that used Holter monitoring. In the other 2 studies, the timing of the Holter monitoring was unclear.

\section{Study Results}

Table 2 shows the number of events throughout the studies. The individual study results are shown in a forest plot (Figure 2) but not pooled due to the considerable clinical and statistical heterogeneity. To show the $P$ values in the context of the study sample size, an albatross plot is presented (Figure 3 ).

Table 2. Study outcomes.

\begin{tabular}{|c|c|c|c|c|c|c|}
\hline Author & Sample size, $\mathrm{n}$ & $\begin{array}{l}\text { Intervention } \\
\text { group, } \mathrm{n}\end{array}$ & $\begin{array}{l}\text { Control group, } \\
\mathrm{n}\end{array}$ & $\begin{array}{l}\text { Events (intervention), } \\
\mathrm{n}(\%)\end{array}$ & $\begin{array}{l}\text { Events (control), } \\
\mathrm{n}(\%)\end{array}$ & Odds ratio $(95 \% \mathrm{CI})$ \\
\hline \multicolumn{7}{|l|}{ Nonpatch studies } \\
\hline Liu et al, 2010 [23] & 92 & $-^{\mathrm{a}}$ & - & $39(42.4)$ & $27(29.2)$ & $1.77(0.96-3.26)$ \\
\hline Hendrikx et al, 2014 [26] & 95 & - & - & $9(9.5)$ & $2(2.1)$ & $4.87(1.02-23.16)$ \\
\hline Kimura et al, 2016 [27] & 28 & - & - & $15(53.6)$ & $6(21.4)$ & $4.23(1.31-13.62)$ \\
\hline Busch et al, 2017 [28] & 1678 & - & - & $42(2.6)$ & $21(1.3)$ & $2.03(1.19-3.44)$ \\
\hline Halcox et al, 2017 [29] & 1001 & 500 & 501 & $19(3.8)$ & $5(1.0)$ & $3.92(1.45-10.58)$ \\
\hline Hickey et al, 2017 [30] & 46 & 23 & 23 & $14(60.9)$ & $7(30.4)$ & $3.56(1.05-12.05)$ \\
\hline Narasimha et al, 2018 [31] & 33 & - & - & $6(18.2)$ & $3(9.1)$ & $2.22(0.51-9.76)$ \\
\hline Reed et al, 2019 [19] & 240 & 124 & 116 & $9(7.3)$ & $0(0)$ & $19.16^{\mathrm{b}}(1.10-333.12)$ \\
\hline Goldenthal et al, 2019 [32] & 238 & 115 & 123 & $58(50.4)$ & $49(41.5)$ & $1.54(0.92-2.57)$ \\
\hline \multicolumn{7}{|l|}{ Patch studies } \\
\hline Rosenberg et al, 2013 [24] & 74 & - & - & $38(51.3)$ & $21(28.4)$ & $2.66(1.35-5.26)$ \\
\hline Barrett et al, 2013 [25] & 146 & - & - & $41(28.1)$ & $27(18.5)$ & $1.72(0.99-2.99)$ \\
\hline Reed et al, 2018 [18] & 689 & 86 & 603 & $2(2.3)$ & $0(0)$ & $35.71^{\mathrm{b}}(1.70-750.18)$ \\
\hline Karunadas et al, 2019 [33] & 141 & - & - & $3(2.1)$ & $3(2.1)$ & $1.00(0.20-5.04)$ \\
\hline Kaura et al, 2019 [34] & 116 & 56 & 60 & $7(16.3)$ & $1(2.1)$ & $8.43(1.00-70.87)$ \\
\hline
\end{tabular}

${ }^{\mathrm{a}}$ Not applicable.

${ }^{\mathrm{b}}$ Haldane correction applied. 
Figure 2. Forest plot of the study results. No pooling due to heterogeneity.

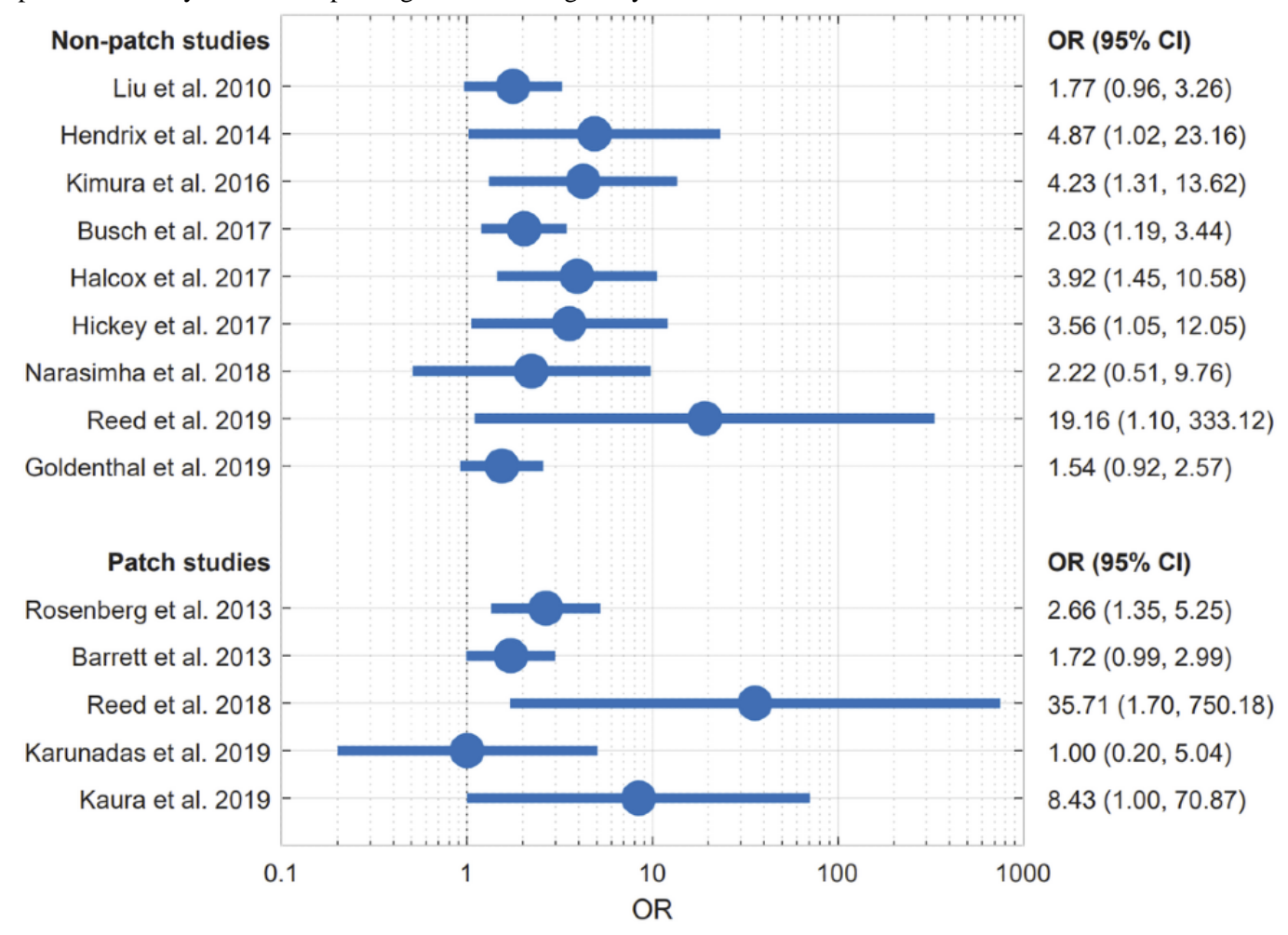

Favors control

Favors intervention

Figure 3. Albatross plot, with plotted odds ratio lines.

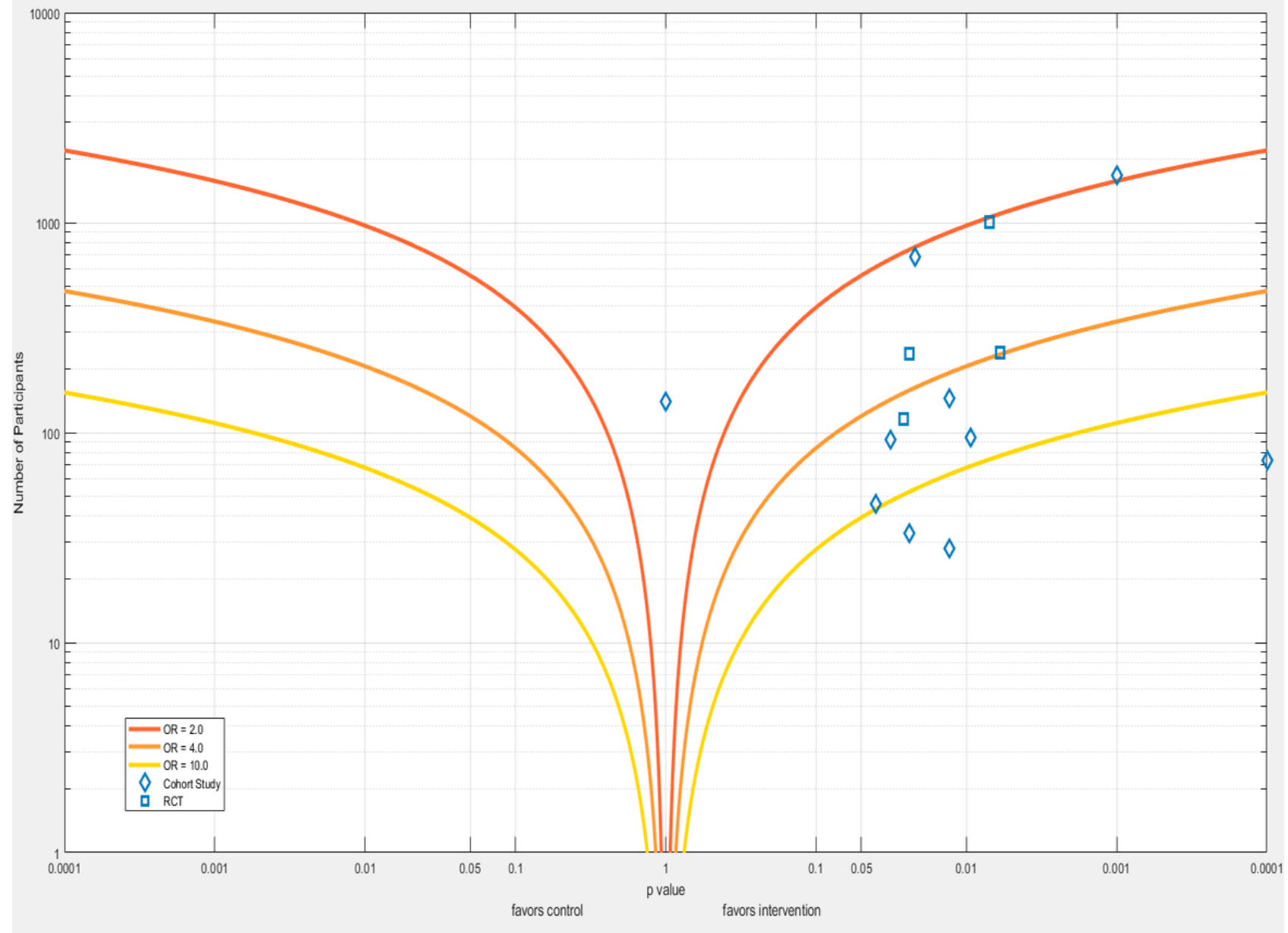


All studies showed a higher AF detection rate in the mHealth group compared with the control group except the study by Karunadas, which showed an equal number of events $(3 ; 2.1 \%)$ in both groups [33]. This study used an mHealth patch for 1 day and compared it to Holter monitoring performed on the same day. The 24-hour to 72-hour patch data have been disregarded for the analysis.

All RCTs showed a statistically significant improvement of AF detection with mHealth devices. ORs were 3.92 (95\% CI 1.45-10.58) for the REHEARSE-AF (Assessment of Remote Heart Rhythm Sampling Using the AliveCor Heart Monitor to Screen for Atrial Fibrillation) trial, 19.16 (95\% CI 1.10-333.12) for IPED, 1.54 (95\% CI 0.92-2.57) in the iHeart (Information Technology Approach to Implementing Depression Treatment in Cardiac Patients) trial, and 8.43 (95\% CI 1.00-70.87) in the EPACS (Early Prolonged Ambulatory Cardiac Monitoring in Stroke) trial.

\section{Statistical Heterogeneity}

The 14 selected studies showed a variety of populations, interventions, and outcomes and are therefore considerably clinically heterogenic. A chi-square test was conducted to assess statistical heterogeneity, which showed a Q of 34.1 and an $I^{2}$ of 61.9 , and therefore the studies show considerable statistical heterogeneity.

\section{Quality Appraisal}

Figure 4 presents the generic risk of bias, assessed with the RoB 2 and ROBINS-I tools. In the selected RCTs, blinding of participants was not possible due to the nature of the intervention. Of all selected RCTs, one had a high risk of bias on the outcome data. Kaura et al [34] reported a dropout of $22.4 \%$ and did not address this data in the report. This was also true for the RCT by Goldenthal et al [32], but the dropout in this trial was just $2.1 \%$. As for allocation concealment in the trial carried out by Halcox et al [29], no clarity was provided in the method section of the paper.

Figure 4. Risk of bias assessment. Randomized trials were assessed with the ROB 2 (Risk of Bias 2) tool, while ROBINS-I was used for nonrandomized studies. ROBINS-I: Risk of Bias in Nonrandomized Studies of Interventions.

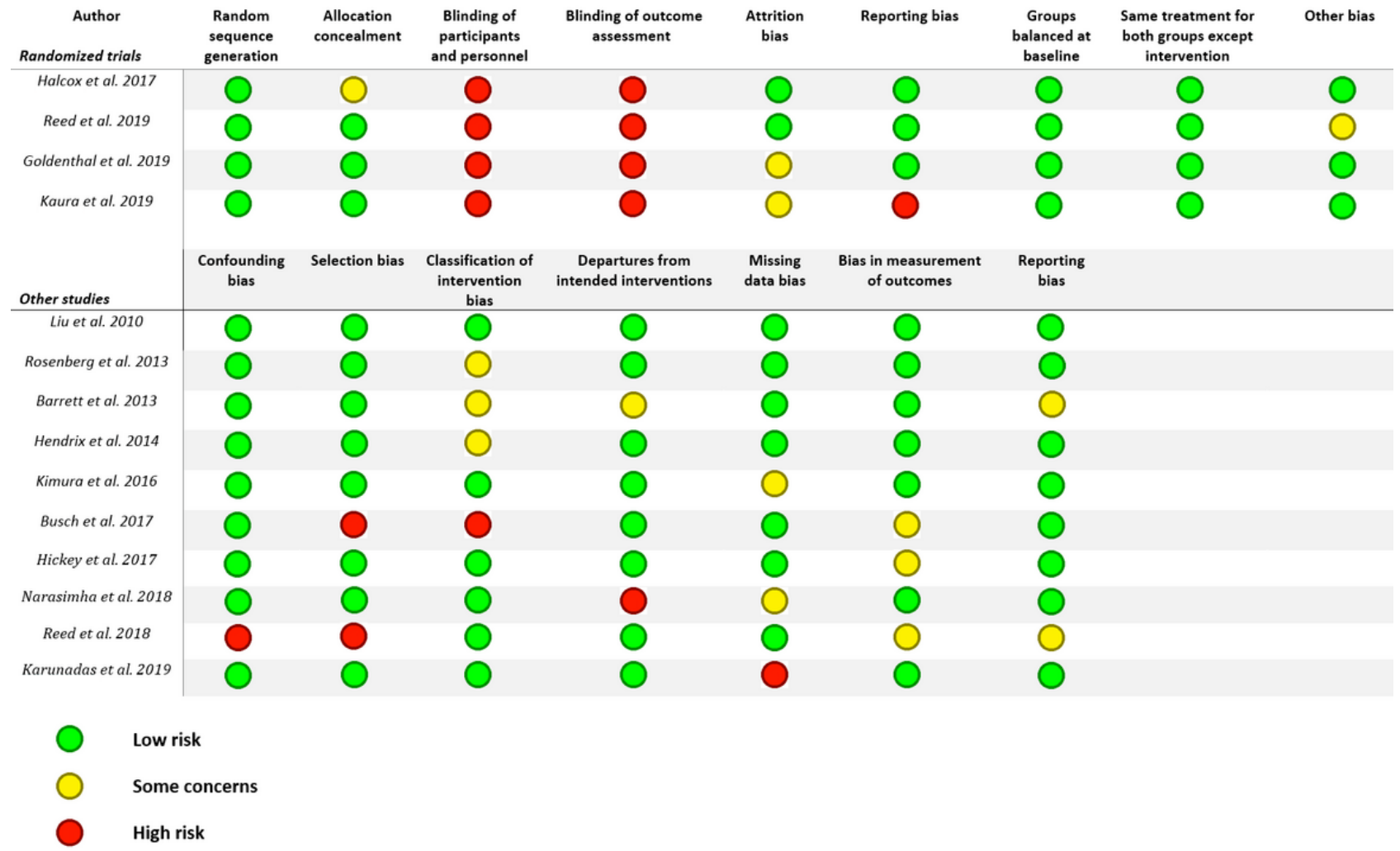

Of the nonrandomized studies, the studies by Liu et al [23], Rosenberg et al [24], Hendrikx et al [26], Kimura et al [27], and Hickey et al [30] were scored as strong. Several studies showed an intermediate risk of bias. Barrett et al [18] reported no baseline characteristics, and Holter timing was unclear. Narasimha et al [25] reported a dropout of $13.2 \%$ but performed separate per-protocol and intention-to-treat analyses. Reed et al [31] used unmatched cohorts with several parameters not being known or stated. Also, there was a time interval of 7 to 8 years between gathering of the data in the intervention and control cohorts.
Two studies showed a high risk of bias. Busch et al [28] used data from a registry, in which the study subjects were volunteers willing to participate in an mHealth study. Karunadas et al [33] reported no baseline characteristics, and only WebCardio data from the first 24 hours were used. The 24-hour to 72-hour data, although gathered, were not reported. 


\section{Discussion}

\section{Summary of Evidence}

The main finding of this systematic review of 14 studies is the increased $\mathrm{AF}$ detection rate when using mHealth devices compared with standard follow-up. Moreover, the 4 RCTs included all showed a statistically significant difference. However, there was a considerable clinical and statistical interstudy heterogeneity. The results of all studies but one show that mHealth devices lead to an increased detection of AF.

An argument can be made that conducting more (spot) measurements will automatically lead to more diagnoses of any illness. However, as AF is often only present for a short period of time and untraceable once sinus rhythm is restored, the clinical implications of the opportunity for conducting more spot measurements could be of importance with regard to stroke risk, for example. Following standard care does not allow patients to record their ECG without a delay, as they must visit their care provider or call an ambulance. Meanwhile, a paroxysm of AF may already have disappeared. Smartphone-connectable ECG devices could therefore provide patients with the opportunity to act immediately by documenting their rhythm disturbance. This is not only true for AF but also for other paroxysmal arrhythmias.

Although both handheld devices and patches lead to an increased AF detection rate, there may be a different use case to both groups of devices. Patches could be seen as prolonged Holter monitoring. The Zio patch can remain on the body for up to 14 days [13]. Handheld devices are used to do spot measurements for a longer period of time and can therefore only be used for screening or in patients with complaints that could fit with a rhythm disturbance. Therefore, the benefit of patches over handheld devices is that asymptomatic rhythm disturbances may be diagnosed with the use of a patch, although patient-triggered recordings with handheld ECG devices may be a more viable solution when a longer period of follow-up is indicated.

\section{Potential of mHealth for Population-Based Screening}

Smartphone-connectable ECG devices cannot only be used in patients with a suspected paroxysmal rhythm disturbance but also for screening purposes. As stroke has been found to be the first symptom of AF in $37 \%$ of patients aged younger than 75 years with no history of cardiovascular diseases, secondary prevention in the form of screening risk groups for AF de novo may be of clinical relevance [37]. When it comes to screening for $\mathrm{AF}$, there are several possibilities. Individuals can be screened regardless of medical history (systematic screening), on presenting to a physician for issues unrelated to $\mathrm{AF}$ (systematic opportunistic screening), or based on the presence of AF-associated risk factors (targeted screening). A recent meta-analysis has shown opportunistic screening, with a number needed to screen of 170 , to be a likely cost-effective use of resources [38]. However, the number needed to screen varies between age groups and is found to be lowest, 83, in patients aged older than 65 years, against 926 for ages 60 to 64 years and 1089 for patients aged younger than 60 years, and therefore screening might be most opportune in people aged older than
65 years [39]. A very recent study using a Monte Carlo simulation to assess the cost-effectiveness of screening for AF with mHealth devices using 30,000 patients per $\mathrm{CHA}_{2} \mathrm{DS}_{2}$-VASc score (1-9) has found this type of screening to cause increased health care costs but a reduction in the incidence of stroke [40]. Several mHealth studies have used a systematic opportunistic screening approach such as screening for AF with handheld devices in individuals who visit pharmacies or those who visit their general practitioner for a flu vaccination [41-45]. These studies have all concluded handheld smartphone-connectable ECG devices to be viable screening tools.

\section{Clinical Implications}

In this era of mHealth, patients are increasingly able to take (spot) measurements by using smartphone-connectable ECG devices, as those devices are commercially available. However, no consensus exists within the scientific community whether each episode of AF should be seen as clinically significant. AF is traditionally defined as an irregular arrhythmia without visible $P$ waves lasting 30 seconds or more or documented on a standard 10-second 12-lead ECG [46]. The Kardia and other devices that register a lead-I ECG document a period of 30 seconds [35]. However, the clinical significance of a short paroxysm of AF is debated. Looking at AF ablation patients, it is known that the quality of life response is proportional to the burden rather than to a short-lived event and the AF burden is also a better predictor for stroke risk compared solely with a history of AF [47,48]. A recent study in patients with pacemakers tested various $\mathrm{AF}$ episode duration thresholds and found that patients with initial AF events up to 3.8 hours only had a median AF burden of $0.2 \%$ compared with $9.5 \%$ for those with initial AF episodes of more than 3.8 hours. This was a statistically significant difference with a $P$ value of <.0001 [49].

\section{Limitations}

Due to considerable clinical and statistic heterogeneity, with an $I^{2}$ of 61.9 , the results of the included studies could not be pooled into a meta-analysis. The study populations varied from healthy adults to patients with an extensive history of AF, interventions ranged from short-term follow-up with a patch to long-term follow-up with a handheld device, and primary outcomes were also diverse. These differences led to a wide spread in the number of detected cases of $\mathrm{AF}$, from $1 \%$ to $3 \%$ in the study by Busch et al [28] to $30 \%$ to $61 \%$ in the study by Hickey et al [30]. Instead of performing a meta-analysis, a forest plot without a diamond and an albatross plot were made. Furthermore, participants in RCTs could not be blinded due to the nature of the intervention. This is a small problem, however, since a diagnosis of AF is not a subjective end point.

\section{Conclusion}

This systematic review reflects on 14 studies with different populations, interventions, and (primary) outcomes. A total of 13 studies found an increased number of AF diagnoses with the use of an mHealth intervention compared with standard care, with the remaining study by Karunadas et al [33] showing equal effectiveness. All 4 RCTs showed a statistically significant result in favor of the mHealth intervention. Due to considerable clinical and statistical heterogeneity, individual study results 
could not be pooled into a meta-analysis, and as a result, it cannot be concluded that those mHealth interventions are effective in certain populations or every population. However, smartphone-connectable ECG devices provide patients with the ability to document a rhythm disturbance more easily than with standard care, and with the introduction of more mHealth devices and specifically devices that can diagnose AF like the Apple Watch (Apple Inc) and Move ECG (Withings) [50,51], this is unlikely to change. With increased patient expectations and the increased empowerment and engagement with regard to their illness that mHealth devices may provide [52], future patients may request mHealth to be a part of their standard follow-up. However, as it is not yet clear when an mHealth-detected episode of AF should be deemed significant [48], clinicians must beware of overdiagnosis of AF and, sequentially, overtreatment with oral anticoagulants.

\section{Conflicts of Interest}

None declared.

\section{Multimedia Appendix 1}

Search strategy.

[DOCX File, 12 KB-Multimedia Appendix 1]

\section{References}

1. Chugh SS, Havmoeller R, Narayanan K, Singh D, Rienstra M, Benjamin EJ, et al. Worldwide epidemiology of atrial fibrillation: a Global Burden of Disease 2010 study. Circulation 2014 Feb 25;129(8):837-847 [FREE Full text] [doi: 10.1161/CIRCULATIONAHA.113.005119] [Medline: 24345399]

2. January CT, Wann LS, Alpert JS, Calkins H, Cigarroa JE, Cleveland JC, American College of Cardiology/American Heart Association Task Force on Practice Guidelines. 2014 AHA/ACC/HRS guideline for the management of patients with atrial fibrillation: a report of the American College of Cardiology/American Heart Association Task Force on Practice Guidelines and the Heart Rhythm Society. J Am Coll Cardiol 2014 Dec 02;64(21):e1-e76 [FREE Full text] [doi: 10.1016/j.jacc.2014.03.022] [Medline: 24685669]

3. Rienstra M, McManus DD, Benjamin EJ. Novel risk factors for atrial fibrillation: useful for risk prediction and clinical decision making? Circulation 2012 May 22;125(20):e941-e946 [FREE Full text] [doi:

10.1161/CIRCULATIONAHA.112.112920] [Medline: 22615425]

4. Kirchhof P, Benussi S, Kotecha D, Ahlsson A, Atar D, Casadei B, et al. 2016 ESC Guidelines for the management of atrial fibrillation developed in collaboration with EACTS. Eur Heart J 2016 Oct 07;37(38):2893-2962. [doi: 10.1093/eurheartj/ehw210] [Medline: 27567408]

5. Pistoia F, Sacco S, Tiseo C, Degan D, Ornello R, Carolei A. The epidemiology of atrial fibrillation and stroke. Cardiol Clin 2016 May;34(2):255-268. [doi: 10.1016/j.ccl.2015.12.002] [Medline: 27150174]

6. Stefansdottir H, Aspelund T, Gudnason V, Arnar DO. Trends in the incidence and prevalence of atrial fibrillation in Iceland and future projections. Europace 2011 Aug;13(8):1110-1117. [doi: 10.1093/europace/eur132] [Medline: 21551478]

7. Lip GYH, Tse HF, Lane DA. Atrial fibrillation. Lancet 2012 Feb 18;379(9816):648-661. [doi: 10.1016/S0140-6736(11)61514-6] [Medline: 22166900]

8. Odutayo A, Wong CX, Hsiao AJ, Hopewell S, Altman DG, Emdin CA. Atrial fibrillation and risks of cardiovascular disease, renal disease, and death: systematic review and meta-analysis. BMJ 2016 Sep 06;354:i4482 [FREE Full text] [doi: 10.1136/bmj.i4482] [Medline: 27599725]

9. Larsen BS, Kumarathurai P, Falkenberg J, Nielsen OW, Sajadieh A. Excessive atrial ectopy and short atrial runs increase the risk of stroke beyond incident atrial fibrillation. J Am Coll Cardiol 2015 Jul 21;66(3):232-241 [FREE Full text] [doi: 10.1016/j.jacc.2015.05.018] [Medline: 26184616]

10. Thakkar S, Bagarhatta R. Detection of paroxysmal atrial fibrillation or flutter in patients with acute ischemic stroke or transient ischemic attack by Holter monitoring. Indian Heart J 2014;66(2):188-192 [FREE Full text] [doi: 10.1016/j.ihj.2014.02.009] [Medline: 24814113]

11. Treskes RW, Van Der Velde ET, Atsma DE, Schalij MJ. Redesigning healthcare: the 2.4 billion euro question-connecting smart technology to improve outcome of patients. Neth Heart J 2016 Jul;24(7-8):441-446. [doi: 10.1007/s12471-016-0834-6] [Medline: 27052894]

12. Duarte R, Stainthorpe A, Mahon J, Greenhalgh J, Richardson M, Nevitt S, et al. Lead-I ECG for detecting atrial fibrillation in patients attending primary care with an irregular pulse using single-time point testing: a systematic review and economic evaluation. PLoS One 2019;14(12):e0226671 [FREE Full text] [doi: 10.1371/journal.pone.0226671] [Medline: 31869370 ]

13. iRhythmTech. URL: http://www.irhythmtech.com [accessed 2020-11-17]

14. Giebel GD, Gissel C. Accuracy of mHealth devices for atrial fibrillation screening: systematic review. JMIR Mhealth Uhealth 2019 Jun 16;7(6):e13641 [FREE Full text] [doi: 10.2196/13641] [Medline: 31199337]

15. Higgins J, Thomas J, Chandler J. Cochrane Handbook for Systematic Reviews of Interventions version 6.0. 2019. URL: https://training.cochrane.org/handbook [accessed 2020-11-17] 
16. Sterne JAC, Savović J, Page MJ, Elbers RG, Blencowe NS, Boutron I, et al. RoB 2: a revised tool for assessing risk of bias in randomised trials. BMJ 2019 Aug 28;366:14898. [doi: 10.1136/bmj.14898] [Medline: $\underline{31462531]}$

17. Sterne JA, Hernán MA, Reeves BC, Savović J, Berkman ND, Viswanathan M, et al. ROBINS-I: a tool for assessing risk of bias in non-randomised studies of interventions. BMJ 2016 Oct 12;355:i4919 [FREE Full text] [Medline: 27733354]

18. Reed MJ, Grubb NR, Lang CC, Gray AJ, Simpson K, MacRaild A, et al. Diagnostic yield of an ambulatory patch monitor in patients with unexplained syncope after initial evaluation in the emergency department: the PATCH-ED study. Emerg Med J 2018 Aug;35(8):477-485. [doi: 10.1136/emermed-2018-207570] [Medline: 29921622]

19. Reed MJ, Grubb NR, Lang CC, O'Brien R, Simpson K, Padarenga M, et al. Multi-centre randomised controlled trial of a smartphone-based event recorder alongside standard care versus standard care for patients presenting to the emergency department with palpitations and pre-syncope: the IPED (Investigation of Palpitations in the ED) study. EClinicalMedicine 2019 Feb;8:37-46 [FREE Full text] [doi: 10.1016/j.eclinm.2019.02.005] [Medline: $\underline{31193636]}$

20. Valenzuela C. [2 solutions for estimating odds ratios with zeros]. Rev Med Chil 1993 Dec;121(12):1441-1444. [Medline: 8085071]

21. Harrison S, Jones HE, Martin RM, Lewis SJ, Higgins JPT. The albatross plot: a novel graphical tool for presenting results of diversely reported studies in a systematic review. Res Synth Methods 2017 Sep;8(3):281-289 [FREE Full text] [doi: 10.1002/jrsm.1239] [Medline: 28453179]

22. McHugh ML. Interrater reliability: the kappa statistic. Biochem Med (Zagreb) 2012;22(3):276-282 [FREE Full text] [Medline: 23092060]

23. Liu J, Fang P, Hou Y, Li X, Liu Y, Wang Y, et al. The value of transtelephonic electrocardiogram monitoring system during the "Blanking Period" after ablation of atrial fibrillation. J Electrocardiol 2010;43(6):667-672. [doi: 10.1016/j.jelectrocard.2010.06.007] [Medline: 20667550]

24. Rosenberg MA, Samuel M, Thosani A, Zimetbaum PJ. Use of a noninvasive continuous monitoring device in the management of atrial fibrillation: a pilot study. Pacing Clin Electrophysiol 2013 Mar;36(3):328-333 [FREE Full text] [doi: 10.1111/pace.12053] [Medline: 23240827]

25. Barrett PM, Komatireddy R, Haaser S, Topol S, Sheard J, Encinas J, et al. Comparison of 24-hour Holter monitoring with 14-day novel adhesive patch electrocardiographic monitoring. Am J Med 2014 Jan;127(1):e11-e17 [FREE Full text] [doi: 10.1016/j.amjmed.2013.10.003] [Medline: 24384108]

26. Hendrikx T, Rosenqvist M, Wester P, Sandström H, Hörnsten R. Intermittent short ECG recording is more effective than 24-hour Holter ECG in detection of arrhythmias. BMC Cardiovasc Disord 2014 Apr 01;14:41 [FREE Full text] [doi: 10.1186/1471-2261-14-41] [Medline: 24690488]

27. Kimura T, Aizawa Y, Kurata N, Nakajima K, Kashimura S, Kunitomi A, et al. Assessment of atrial fibrillation ablation outcomes with clinic ECG, monthly 24-h Holter ECG, and twice-daily telemonitoring ECG. Heart Vessels 2017 Mar;32(3):317-325. [doi: 10.1007/s00380-016-0866-2] [Medline: 27385021]

28. Busch MC, Gross S, Alte D, Kors JA, Völzke H, Ittermann T, et al. Impact of atrial fibrillation detected by extended monitoring: a population-based cohort study. Ann Noninvasive Electrocardiol 2017 Nov;22(6):1. [doi: 10.1111/anec.12453] [Medline: 28440600]

29. Halcox JPJ, Wareham K, Cardew A, Gilmore M, Barry JP, Phillips C, et al. Assessment of remote heart rhythm sampling using the alivecor heart monitor to screen for atrial fibrillation: the REHEARSE-AF study. Circulation 2017 Nov 07;136(19):1784-1794. [doi: 10.1161/CIRCULATIONAHA.117.030583] [Medline: 28851729]

30. Hickey K, Biviano A, Garan H, Sciacca RR, Riga T, Warren K, et al. Evaluating the utility of mHealth ECG heart monitoring for the detection and management of atrial fibrillation in clinical practice. J Atr Fibrillation 2017;9(5):1546 [FREE Full text] [doi: 10.4022/jafib.1546] [Medline: 29250277]

31. Narasimha D, Hanna N, Beck H, Chaskes M, Glover R, Gatewood R, et al. Validation of a smartphone-based event recorder for arrhythmia detection. Pacing Clin Electrophysiol 2018 May;41(5):487-494. [doi: 10.1111/pace.13317] [Medline: 29493801]

32. Goldenthal IL, Sciacca RR, Riga T, Bakken S, Baumeister M, Biviano AB, et al. Recurrent atrial fibrillation/flutter detection after ablation or cardioversion using the AliveCor KardiaMobile device: iHEART results. J Cardiovasc Electrophysiol 2019 Nov;30(11):2220-2228 [FREE Full text] [doi: 10.1111/jce.14160] [Medline: 31507001]

33. Karunadas CP, Mathew C. Comparison of arrhythmia detection by conventional Holter and a novel ambulatory ECG system using patch and Android app over 24 hour period. Indian Pacing Electrophysiol J 2020;20(2):49-53 [FREE Full text] [doi: 10.1016/j.ipej.2019.12.013] [Medline: 31866554]

34. Kaura A, Sztriha L, Chan FK, Aeron-Thomas J, Gall N, Piechowski-Jozwiak B, et al. Early prolonged ambulatory cardiac monitoring in stroke (EPACS): an open-label randomised controlled trial. Eur J Med Res 2019 Jul 26;24(1):25 [FREE Full text] [doi: 10.1186/s40001-019-0383-8] [Medline: $\underline{31349792]}$

35. AliveCor. URL: https://www.alivecor.com/ [accessed 2020-11-17]

36. Zenicor. URL: https://www.zenicor.com/ [accessed 2020-11-17]

37. Jaakkola J, Mustonen P, Kiviniemi T, Hartikainen JEK, Palomäki A, Hartikainen P, et al. Stroke as the first manifestation of atrial fibrillation. PLoS One 2016;11(12):e0168010 [FREE Full text] [doi: 10.1371/journal.pone.0168010] [Medline: 27936187] 
38. Welton NJ, McAleenan A, Thom HH, Davies P, Hollingworth W, Higgins JP, et al. Screening strategies for atrial fibrillation: a systematic review and cost-effectiveness analysis. Health Technol Assess 2017 May;21(29):1-236 [FREE Full text] [doi: 10.3310/hta21290] [Medline: 28629510]

39. Lowres N, Olivier J, Chao T, Chen S, Chen Y, Diederichsen A, et al. Estimated stroke risk, yield, and number needed to screen for atrial fibrillation detected through single time screening: a multicountry patient-level meta-analysis of 141,220 screened individuals. PLoS Med 2019 Sep;16(9):e1002903 [FREE Full text] [doi: 10.1371/journal.pmed.1002903] [Medline: 31553733]

40. Giebel GD. Use of mHealth devices to screen for atrial fibrillation: cost-effectiveness analysis. JMIR Mhealth Uhealth 2020 Oct 06;8(10):e20496 [FREE Full text] [doi: 10.2196/20496] [Medline: $\underline{\text { 33021489] }}$

41. Bacchini M, Bonometti S, Del Zotti F, Lechi A, Realdon F, Fava C, et al. Opportunistic screening for atrial fibrillation in the pharmacies: a population-based cross-sectional study. High Blood Press Cardiovasc Prev 2019 Aug;26(4):339-344. [doi: 10.1007/s40292-019-00334-4] [Medline: $\underline{31385256]}$

42. Lowres N, Neubeck L, Salkeld G, Krass I, McLachlan AJ, Redfern J, et al. Feasibility and cost-effectiveness of stroke prevention through community screening for atrial fibrillation using iPhone ECG in pharmacies: the SEARCH-AF study. Thromb Haemost 2014 Jun;111(6):1167-1176. [doi: 10.1160/TH14-03-0231] [Medline: 24687081]

43. Lowres N, Krass I, Neubeck L, Redfern J, McLachlan AJ, Bennett AA, et al. Atrial fibrillation screening in pharmacies using an iPhone ECG: a qualitative review of implementation. Int J Clin Pharm 2015 Dec;37(6):1111-1120. [doi: 10.1007/s11096-015-0169-1] [Medline: 26202627]

44. Kaasenbrood F, Hollander M, Rutten FH, Gerhards LJ, Hoes AW, Tieleman RG. Yield of screening for atrial fibrillation in primary care with a hand-held, single-lead electrocardiogram device during influenza vaccination. Europace 2016 Oct;18(10):1514-1520 [FREE Full text] [doi: 10.1093/europace/euv426] [Medline: 26851813]

45. Orchard J, Lowres N, Freedman SB, Ladak L, Lee W, Zwar N, et al. Screening for atrial fibrillation during influenza vaccinations by primary care nurses using a smartphone electrocardiograph (iECG): a feasibility study. Eur J Prev Cardiol 2016 Dec;23(2 suppl):13-20. [doi: 10.1177/2047487316670255] [Medline: 27892421]

46. Calkins H, Brugada J, Packer DL, Cappato R, Chen S, Crijns HJG, Heart Rhythm Society, European Heart Rhythm Association, European Cardiac Arrhythmia Society, American College of Cardiology, American Heart Association, Society of Thoracic Surgeons. HRS/EHRA/ECAS expert consensus statement on catheter and surgical ablation of atrial fibrillation: recommendations for personnel, policy, procedures and follow-up. A report of the Heart Rhythm Society (HRS) Task Force on Catheter and Surgical Ablation of Atrial Fibrillation developed in partnership with the European Heart Rhythm Association (EHRA) and the European Cardiac Arrhythmia Society (ECAS); in collaboration with the American College of Cardiology (ACC), American Heart Association (AHA), and the Society of Thoracic Surgeons (STS). Endorsed and approved by the governing bodies of the American College of Cardiology, the American Heart Association, the European Cardiac Arrhythmia Society, the European Heart Rhythm Association, the Society of Thoracic Surgeons, and the Heart Rhythm Society. Europace 2007 Jun;9(6):335-379. [doi: 10.1093/europace/eum120] [Medline: 17599941]

47. Mantovan R, Macle L, De Martino G, Chen J, Morillo CA, Novak P, et al. Relationship of quality of life with procedural success of atrial fibrillation (AF) ablation and postablation AF burden: substudy of the STAR AF randomized trial. Can J Cardiol 2013 Oct;29(10):1211-1217. [doi: 10.1016/j.cjca.2013.06.006] [Medline: 23988341]

48. Boriani G, Glotzer TV, Santini M, West TM, De Melis M, Sepsi M, et al. Device-detected atrial fibrillation and risk for stroke: an analysis of $>10,000$ patients from the SOS AF project (Stroke preventiOn Strategies based on Atrial Fibrillation information from implanted devices). Eur Heart J 2014 Feb;35(8):508-516 [FREE Full text] [doi: 10.1093/eurheartj/eht491] [Medline: 24334432]

49. Steinberg JS, O'Connell H, Li S, Ziegler PD. Thirty-second gold standard definition of atrial fibrillation and its relationship with subsequent arrhythmia patterns. Circ Arrhythm Electrophysiol 2018 Jul;11(7):e006274. [doi: 10.1161/circep.118.006274]

50. Apple Inc. URL: https://support.apple.com/en-us/HT208955 [accessed 2020-11-17]

51. Withings. URL: https://www.withings.com/ [accessed 2020-11-17]

52. Risling T, Martinez J, Young J, Thorp-Froslie N. Evaluating patient empowerment in association with eHealth technology: scoping review. J Med Internet Res 2017 Sep 29;19(9):e329 [FREE Full text] [doi: 10.2196/jmir.7809] [Medline: 28963090]

\section{Abbreviations}

AF: atrial fibrillation

$\mathbf{C H A}_{2} \mathbf{D S}_{2}$-VASc: congestive heart failure, hypertension, age $\geq 75$ years, diabetes mellitus, stroke or transient ischemic attack (TIA), vascular disease, age 65 to 74 years, sex category

ECG: electrocardiogram

EPACS: Early Prolonged Ambulatory Cardiac Monitoring in Stroke

iHeart: An Information Technology Approach to Implementing Depression Treatment in Cardiac Patients

IPED: Investigation of Palpitations in the Emergency Department

mHealth: mobile health

OR: odds ratio 
PAC: premature atrial contraction

PATCH-ED: Patch Monitor in Patients With Unexplained Syncope After Initial Evaluation in the Emergency

Department

RCT: randomized controlled trial

REHEARSE-AF: Assessment of Remote Heart Rhythm Sampling Using the AliveCor Heart Monitor to Screen for Atrial Fibrillation

RoB 2: Risk of Bias 2

ROBINS-I: Risk Of Bias in Nonrandomized Studies of Interventions

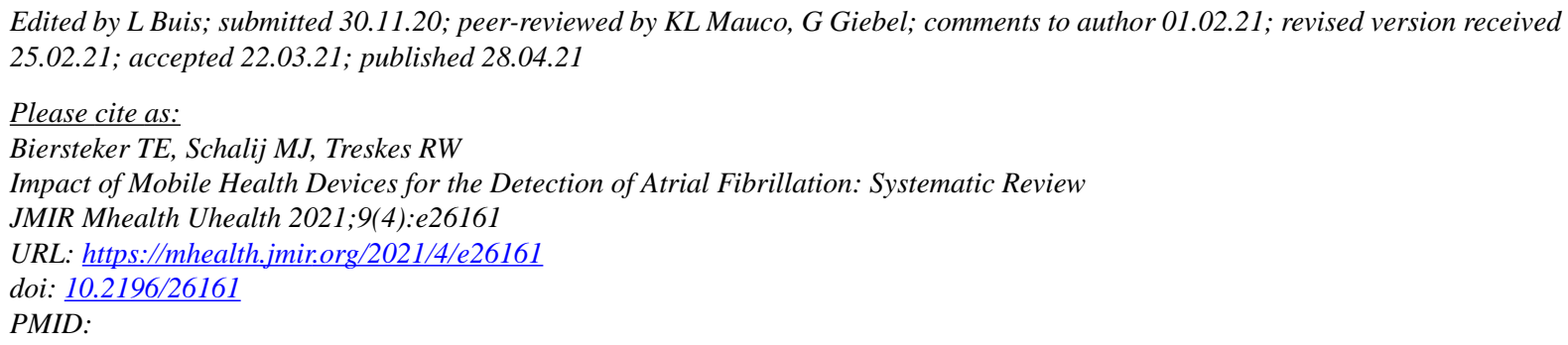

(CTom E Biersteker, Martin J Schalij, Roderick W Treskes. Originally published in JMIR mHealth and uHealth (https://mhealth.jmir.org), 28.04.2021. This is an open-access article distributed under the terms of the Creative Commons Attribution License (https://creativecommons.org/licenses/by/4.0/), which permits unrestricted use, distribution, and reproduction in any medium, provided the original work, first published in JMIR mHealth and uHealth, is properly cited. The complete bibliographic information, a link to the original publication on http://mhealth.jmir.org/, as well as this copyright and license information must be included. 